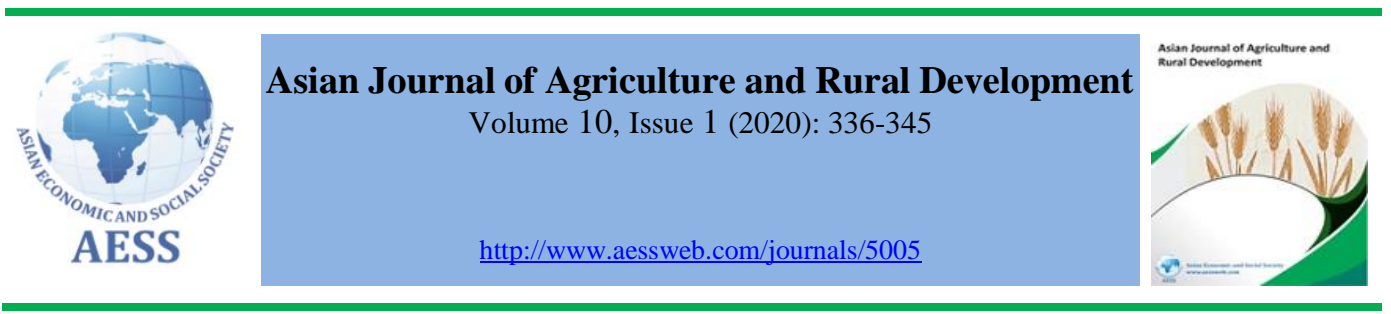

\title{
TRENDS IN PROFITABILITY AMIDST PRODUCTION CONSTRAINTS ENCOUNTERED BY SMALLHOLDER MANGO GROWERS - A CASE OF INDIA
}

Mehjabeen ${ }^{\mathrm{a}}$

A. Saravana Durai ${ }^{a}$ a Department of Economics, Periyar University, Salem, Tamil Nadu, India

- mehjabeen.nish@gmail.com (Corresponding author)

\section{ARTICLE HISTORY: \\ Received: 06-Mar-2020 \\ Accepted: 06-May-2020 \\ Online Available: 09-Jun- \\ 2020}

\section{Keywords:}

Artificial-ripening,

Distribution, ground-water depletion, profit-margin loss, welfare-economics

ABSTRACT
This paper highlights constraints faced by smallholder mango growers
of a sub-district which, is classified into two categories i.e. Technical
Constraints and Economic \& Marketing Constraints. It also analyzes
and explains the effect of agricultural activities on environmental
degradation, health, and climate change. Based on the constraints, the
data was used from April 2016 to March 2017. A sample of 320
smallholder mango growers of region Srinivaspur; a sub-district of
Kolar, India was collected by a structured interview. We have used
the arithmetic mean, percentage method, and ranking method for
empirical analysis.

\section{Contribution/ Originality}

The research explores the reasons behind the issues faced by smallholder mango growers like; high APMC commission, and lower rainfall. It also finds why agriculture activities are affecting the health, environment, and how it is one of the causes of climate change.

DOI: 10.18488/journal.1005/2020.10.1/1005.1.336.345

ISSN (P): 2304-1455/ISSN (E):2224-4433

How to cite: Mehjabeen and A. Saravana Durai (2020). Trends in profitability amidst production constraints encountered by smallholder mango growers - a case of India. Asian Journal of Agriculture and Rural Development, 10(1), 336-345.

(C) 2020 Asian Economic and Social Society. All rights reserved. 


\section{INTRODUCTION}

India ranks first in the production of Mangoes inclusive of mangosteens \& guavas, banana, and papayas that contribute about $40.4 \%, 25.7 \%$, and $43.6 \%$ respectively, towards the total fruit production of the country. In the year 2018-19, India's fruit and vegetable export were USD 1469.33 million, in which fruits were of USD 692.01 Million, and vegetables of USD 777.25 Million (APEDA Ministry of Commerce and Industry, 2020). India contributes almost 50\% of the world's total mango production followed by China, Mexico, and Thailand. Mango-producing countries are mostly 'developing countries.' Therefore, there is a lot of scope for research and development.

Kolar district shows the highest trend in mango cultivation among other districts. In the year 201415, the area under fruit cultivation was 58931 hectares and the production was 601159 tons, out of which the area under mango cultivation was 48824 hectares i.e. $82.85 \%$ and its production was 390961 tons i.e. $65.03 \%$ of the total fruits produced in the district. Among other sub-districts in the district, Srinivaspur not only shows a trend of the largest area under mango cultivation but also stands first in Karnataka. The area under the geography of the sub- district is 863 square kilometres i.e. 86300 hectares. There are around 40886 total cultivators (Main+ Marginal) in which 25,355 are males and 15,531 females. The total area under mango cultivation in the district is 49638 hectares; out of which, Srinivaspur sub-district holds 25125 hectares,i.e.50.62\% of the total area under mango cultivation in the district and, total production in the district is 421192 tons out of which Srinivaspur sub-district have 215263 tons i.e. $51.11 \%$ of the total mango production in the district (Department of Horticulture, 1997- 2015; Government of Karnataka, 2016). This is why it is called The Land of World Famous Mangoes.

Average rainfall in the sub-district is $745 \mathrm{~mm} @ 45$ rainy day and average rainy-day month-wise is not more than 8 days. The highest rainfall is recorded in September which is almost the same for many years. Irrigated area in the sub-district has increased and the means of irrigation is mainly bore-well. Ground-water is reported to over-exploited (Government of Karnataka, 2016).

Due to climate change mango arrival early in the Karnataka and Andhra Pradesh market which has resulted in the arrival of the fruit at the same time from all the five peninsula India's state i.e. Karnataka, Andhra Pradesh, Telengana, Kerala and Tamil Nadu creating high supply (Kamalapathi, 2017; Kuruvilla, 2020). Due to thunderstorm with light rain in April 2019 mango shower took place in few of the areas in Karnataka, Kerala, Telengana, Tamil Nadu and Maharashtra resulting in a loss in yield due to climate change (Chennailyil Oru Mazhaikkaalam, 2019) It was reported that mango tastes sour in Kerala. The mango orchards didn't flower in November. The farmers were afraid of loss as the market might have been flooded with mangoes from all the south Indian states at the same time. The reasons for late flowering were unseasonal rainfall and rising temperature. They also feared 'Thrips' an insect that sucks the latex from the mango flower and also responsible for deformation and decolourize fruits (Kuruvilla, 2020).

A case study report says Shree Kishan Suman, a Kota-based horticulturist and farmer have identified in the year 2000 a mango tree which has bloomed three times i.e. January- February, June-July and September-October. He named the variety as 'Sadabahar' which, is also immune to many diseases (The Better Home, 2018).

Farmers dumped the mangoes on roads due to the crashing of the wholesale price. Alphonso mangoes were sold at USD 1.04/ kg in retail markets were sold in USD 0.104/ kg in the APMC wholesale market. Totapuri and Raspuri have reported to sold at the lowest price of USD $0.052 / \mathrm{kg}$ in Ramanagaram (Kumar, 2018). Mango output has increased by $8 \%$ in India. Utter Pradesh, Andhra Pradesh and Karnataka by 0.2, 0.44 and 0.1 million tonnes respectively. 
The European Union banned the import of Indian mangoes and four vegetables. The first reason was the fruit flies lay eggs in the immature mangoes which are hatched during the ripping stage of mangoes and the maggots feed on the flesh of it (Ganesan, 2014; Goyal et al., 2017). The second reason was the use of calcium carbide to ripen the mango artificially which could cause diarrhea, mouth ulcers, and also cancer. It also has some quantity of arsenic and phosphorus hydride. Calcium carbide also degrades the taste where the mangoes look ripen on its skin but inside it remains raw. The report also mentioned that how the pesticide shop owner misguide the illiterate and greedy farmers (Ganesan, 2014; Khan, 2017) Despite a ban on artificial ripening and the use of Calcium Carbide under the Prevention of Food Adulteration (PFA) Act, 1954 and the prevention of food where the convict shall face imprisonment for three years and a fine of up to Rupees 1000 still, in India it is used. Apart from Calcium Carbide, Ethylene and Ethephon are some other chemicals used for artificial ripening which is a little less harmful and permissible if used in a limited concentration. (Khan, 2017).

The recommended amount of macronutrients is roughly $1 \mathrm{~kg} /$ tree (Leandro, 2016) where the ratio of $\mathrm{N}: \mathrm{P}: \mathrm{K}$ is recommended to be $1.1: 1.4: 1.8 \mathrm{~kg}$ tree-1 (Peralta-Antonio et al., 2014) The Soil Health Card is provided to the farmers intermittently in the span of every two years and doesn't contain the information regarding the volume of mobile nutrients and immobile nutrients in the soil sample (Department of Agriculture, Cooperation and Farmers Welfare, 2014; Reddy, 2018).

Phosphate fertilizers contain toxic elements such as Cadmium (Cd), Uranium (U), Mercury (Hg), Lead $(\mathrm{Pb})$, Iron $(\mathrm{Fe})$, Molybdenum (Mo), Radium ( $\mathrm{Ra})$, and Chromium $(\mathrm{Cr})$ which is gathering in the soils over the years. Few experiments show significant accumulation of these metals in plant tissues. It has been found that the accumulation of heavy metal has been increasing eventually by chemical fertilizer application especially in the root and shoot and the concentration of $\mathrm{Cd}$ and $\mathrm{Pb}$ has been reported high. $\mathrm{Cd}$ is the only metal that has proved to have the highest transfer ratio from soil to plant cells and then to the human body which is a disease-causing factor in the long run. Uranium $(\mathrm{U})$ is abundant in the environment but it is considered to be a non-essential element for the human body. The average human gastrointestinal absorption of uranium is $1-2 \%$. Uranium accumulation takes place in the human body when uranyl iron replaces calcium in the Hydroxyapatite complex of crystals. Uranium enters into the human body through food-chain and it is known for the cause of Nephritis disease (Wuana and Okieimen, 2011; Dissanayake and Chandrajith, 2009; Gupta et al., 2014). It has been found out via samples of urine and drinking water of 325 people that the medium uranium concentration in drinking water is $2 \mu \mathrm{g} / \mathrm{L}$ and in urine, its $13 \mathrm{ng} / \mathrm{mmol}$ creatinine, from which the result drawn was the daily median intake of uranium is $39 \mu \mathrm{g}$. Cadmium $(\mathrm{Cd})$ is another non-essential element and has no physiological function in the human body. The resorption of cadmium in the human body could be pulmonary, gastrointestinal, and dermal. Anemic people showed 6\% more intake of $\mathrm{Cd} . \mathrm{Cd}$ is accumulated mostly in the kidney and stays there for 10 years. It leads to tubules cell necrosis if the accumulation is more. If $2.5 \mu \mathrm{g} \mathrm{Cd} / \mathrm{g}$ of creatinine shows it leads to renal tubular damage by $4 \%$. Itai-Itai disease caused due to Cadmium poisoning leads to bone damage (Dissanayake and Chandrajith, 2009; Wuana and Okieimen, 2011; Gupta et al., 2014).

\section{MATERIALS AND METHODS}

We carried out the fieldwork at Srinivaspur sub-district of Kolar District, Karnataka in India in the Month of March-April; 2017. The study covered the period from March 2016 to April 2017. We randomly interviewed 320 smallholder mango growers using a structured interview schedule. There are 5 blocks in the sub-district namely; Kasba, Yeldur, Ronur, Raylpad and Nelvanki. We interviewed 20 smallholder mango growers from three villages in each block i.e. 15 villages and 20 more mango growers were also randomly, who have visited the horticulture department located in the Srinivaspur town for getting a clear picture. We have considered those farmers who have land holdings from 2.5 to 5 acres and whose $50 \%$ of the total income from mango cultivation for this 
research. The reason to conduct the research is Srinivaspur specializes in mango cultivation and it has a well-defined supply chain. We wanted to explore that rather than specializing mango whether the farmers are free from production, technical and economic \& marketing constraints? We attempted to know the effect of agricultural activities and their impact on environmental degradation and climate change. These effects of climate change and environmental degradation also affected agriculture. These effects of agricultural activities and environmental degradation can also felt in the health of stake-holders. We have analyzed the data and constructed chat using Microsoft excel 2016. We have used arithmetic mean, percentage method and average priority sorting for showing results.

\section{RESULTS AND DISCUSSION}

\subsection{Effect of production constraints on the profitability of the respondents}

- $\quad 80.93 \%$ and $54.43 \%$ of the respondents face late-flowering \& under formation of fruits and lack of knowledge about identifying pests and diseases and, they ranked both the issues second. Some diseases have been introduced in recent years of which farmers do not know. For instance, 'Thrips' is one of the new pests in the sub-district that spoils $50 \%$ of the total mango yield, leading to income loss for the farmers

- $18.75 \%$ of the respondents revealed that they don't have suitable soil for the expansion of the mango orchard and they ranked it sixth. Mostly, the respondents are from the Rayalpad block. The block is covered by rock-bed. Therefore, the available area for cultivation is less. The soil of this area contains rock granule which is not farmer-friendly which is a constraint to enhance the profit margin by expanding the area under cultivation.

- $35 \%$ of the respondents complained about the non-availability of reliable varieties and planting material and they ranked it forth. There are some specific varieties like 'Totapuri' which is largely grown in the sub-district by the farmers to enhance their profitability. The respondents are not very happy with the varieties they get from government-owned nurseries. Therefore, they buy planting materials from private nurseries which are stopping them to try new varieties which could give a better yield and intensify their profitability.

- $6.56 \%$ and $12.8 \%$ of the respondents said that they don't have enough knowledge about the profitability of mango and rejuvenation timespan. They are mostly respondents who have leased-out their crops to the village contractors where they lose their profitability.

- $33.13 \%$ of the respondents are unhappy with the non-availability of market infrastructure. They said that there is no other horticulture market like HOPCOMs in the sub-district. They are supposed to sell the produce in the APMC wholesale market which is cutting short their profit margin. The respondents ranked it sixth.

- $61.56 \%$ of the respondents said they have inadequate market channels and ranked it fifth. Three types of channels exist in the sub-district according to the primary data analysis i.e.:

a) Farmers $\rightarrow$ APMC Commission Agents $\rightarrow$ Wholesalers $\rightarrow$ Retailers $\rightarrow$ Consumers

b) Farmers $\rightarrow$ Village Contractors $\rightarrow$ APMC Commission Agents $\rightarrow$ Wholesalers $\rightarrow$ Retailers $\rightarrow$ Consumers

c) Farmers $\rightarrow$ APMC Commission Agents $\rightarrow$ Retailers $\rightarrow$ Consumers 
Table 1: Constraints encountered by the mango growers

\begin{tabular}{clccc}
\hline \multicolumn{1}{c}{ Constraints } & $\begin{array}{c}\text { Total } \\
\text { Score }\end{array}$ & $\begin{array}{c}\text { Mean } \\
\text { Score }\end{array}$ & $\begin{array}{c}\text { Rank } \\
\text { order* }\end{array}$ \\
\hline I & Technical constraints & & & \\
1 & $\begin{array}{l}\text { Non-availability of reliable varieties and plant } \\
\text { material }\end{array}$ & 112 & 35 & IV \\
2 & Suitability of soil & 60 & 18.75 & VI \\
3 & Rejuvenation timespan & 41 & 12.81 & VI \\
4 & Farmer's knowledge about the profitability of & 21 & 6.56 & IV \\
& mangoes & & & \\
5 & Lack of knowledge about identifying pests and & 187 & 58.43 & II \\
& diseases & 259 & 80.93 & II \\
6 & Late flowering and under formation of fruit & 192 & 60 & II \\
7 & Lack of irrigation facilities & 215 & 67.18 & I \\
8 & Deficit rainfall & & & \\
II & Economic and Marketing Constraints & 106 & 33.13 & VI \\
9 & Non-availability of market infrastructure & 320 & 100 & V \\
10 & Lack of process industry & 214 & 66.88 & II \\
11 & Price fluctuation & 221 & 69.06 & III \\
12 & Lack of storage facilities & 197 & 61.56 & V \\
13 & Inadequate market channels & 320 & 100 & I \\
14 & The high cost of labour & 320 & 100 & I \\
\hline
\end{tabular}

* Rank order is the average of priority sorting (Ordinal Ranking) by the respondents. For instance: 215 respondents i.e. $67.18 \%$ who are facing Deficit Rainfall as the most genuine problem, ranked it I whereas, 259 i.e. $80.93 \%$ of the respondents have considered late flowering and under formation of fruit is a genuine problem but not as genuine as deficit rainfall so they ranked it II.

It shows that there are always APMC commission agents involved in the business which is restricting the farmers from earning more profits out of their produces. Farmers feel it is easier to sell theirs produces in the APMC market rather than coming to the cities and selling them off. The constraints subsequently enhance the cost of production (Kahangi, 2002; Shiferaw et al., 2011; Arphaxard et al., 2019) There could be more convenient marketing channels with the introduction of retailers to the farmers or by establishing process industries.

- $\quad 69.06 \%$ of the respondents said that there are no storage facilities for the mango. They ranked it third. It could help them to sell the fruits in the off-season which would increase their profitability.

- $100 \%$ of the respondents said that there is no processing industry in the sub-district. They ranked it fifth. It could create a better distribution which would in-turn reduce the profit margin loss of the growers.

- All respondents said that hired human labour cost is too high in the sub-district and allotted the first rank to the constraint. The wage rate fluctuates from USD 5.2 to USD 6.5 for male labour and USD 2.6 to USD 3.9 for female labour. None of the respondents is aware of villagers opting for the MGNREGA for their employment needs.

- All of the respondents said that the APMC commission charges are too high and they rank the constraints as number one. The APMC commission agents charge 10\% from the gross income whereas the actual commission charges fixed by the government is $2 \%$.

*Note: Effect of production constraints on the profitability of the respondents are from Table 1. 
Table 2: Chemical-fertilizer, Pesticides and other chemicals utilized by mango growers

\begin{tabular}{|c|c|c|c|}
\hline 1 & $\begin{array}{l}\text { Is the fertilizer you use based on the } \\
\text { recommendation of the authorized person? }\end{array}$ & Yes-0 $(0 \%)$ & No-320 $(100 \%)$ \\
\hline 2 & $\begin{array}{l}\text { The more you use chemical fertilizer the more } \\
\text { yield will be. Do you agree with the statement? }\end{array}$ & Yes-100 (31.25\%) & No-220 $(68.75 \%)$ \\
\hline 3 & $\begin{array}{l}\text { Chemical fertilizers and pesticides don't have } \\
\text { any side effects on soil and its future } \\
\text { productivity. Do you agree? }\end{array}$ & Yes-320 (100\%) & No-0 $(0 \%)$ \\
\hline 4 & $\begin{array}{l}\text { The use of Pesticides doesn't have any bad effect } \\
\text { on health. Do you agree? }\end{array}$ & Yes-263 (82.19\%) & No-57 (17.81\%) \\
\hline 5 & $\begin{array}{l}\text { The use of chemical fertilizer doesn't have any } \\
\text { bad effects on health. Do you agree? }\end{array}$ & Yes-320 (100\%) & No-0 $(0 \%)$ \\
\hline 6 & $\begin{array}{l}\text { I don't use organic fertilizer because it's costly } \\
\text { compared to chemical fertilizer }\end{array}$ & Yes-320 (100\%) & No-0 $(0 \%)$ \\
\hline 7 & I use calcium carbide for artificial ripening & Yes-30 $(9.38 \%)$ & No-290 $(90.63 \%)$ \\
\hline 8 & I use of Ethylene for artificial ripening & Yes-0 $(0 \%)$ & No-320 $(100 \%)$ \\
\hline 9 & I use of Ethephon for artificial ripening & Yes-0 $(0 \%)$ & No-320 (100\%) \\
\hline 10 & $\begin{array}{l}\text { Number of respondents who use the particular } \\
\text { chemical fertilizer to grow/acre in a year }\end{array}$ & $\begin{array}{l}\text { Name of the } \\
\text { fertilizer }\end{array}$ & $\begin{array}{l}\text { Corresponding } \\
\text { weight }\end{array}$ \\
\hline 10.1 & $320(100 \%)$ & $\begin{array}{l}\mathrm{DAP}(50 \mathrm{~kg} / \mathrm{bag}) \mathrm{N} \\
=18 \%, \mathrm{P}=46 \%\end{array}$ & 150 \\
\hline 10.2 & $100(31.25 \%)$ & $\begin{array}{l}\mathrm{SSP}(50 \mathrm{Kg} / \mathrm{bag}) \mathrm{P} \\
=14 \%, \mathrm{~S}=16 \% \\
\mathrm{Ca}=19 \%\end{array}$ & 200 \\
\hline 10.3 & $320(100 \%)$ & $\begin{array}{c}\text { Urea }(45 \mathrm{Kg} / \mathrm{bag}) \mathrm{N} \\
=46 \%\end{array}$ & 180 \\
\hline 10.4 & $124(38.75 \%)$ & Others & 300 \\
\hline
\end{tabular}

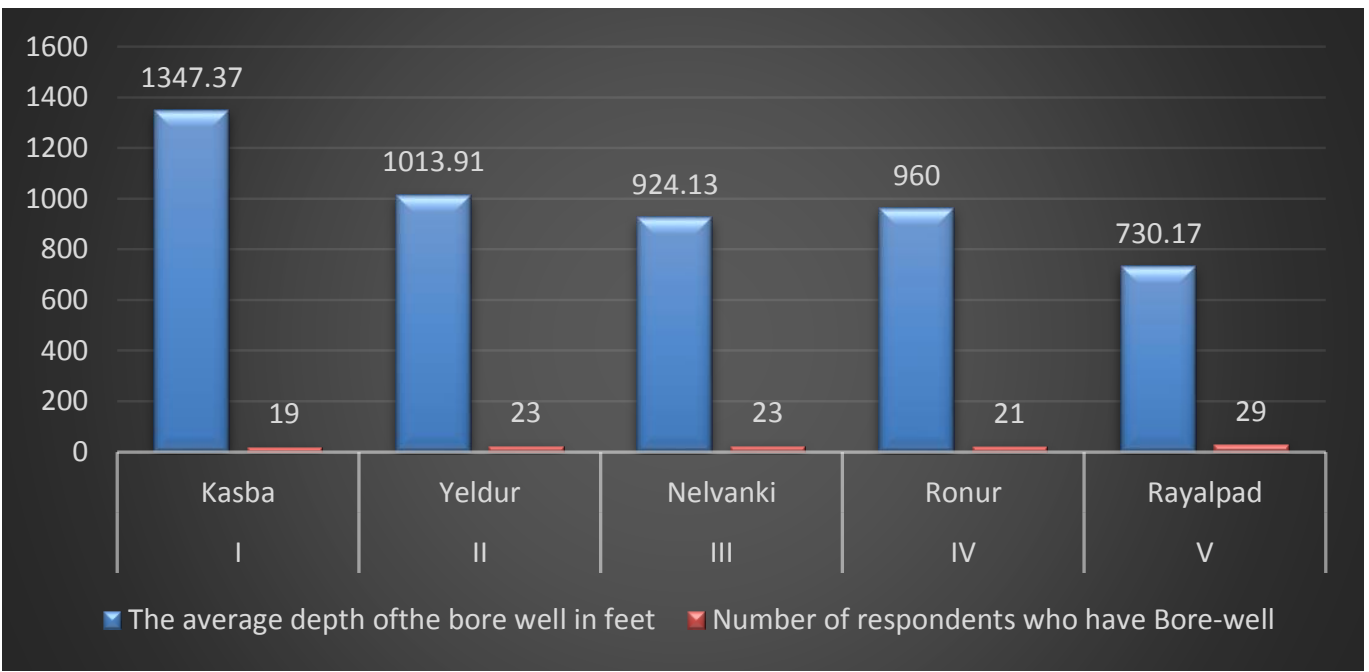

Figure 1: Block-wise relationship between the bore-well holders and the depth of the borewell

Note: We have considered 60 respondents from each block. 20 respondents have been excluded as they were interviewed in the horticulture office but not in their respective villages. Therefore, 300 respondents from the sub-district were been considered for evaluating the relationship between the depth of the bore-well and the 
number of respondents those who hold bore-well. The average depth of the bore-well in the sub-district is $979.652 \mathrm{ft}$.

We give our insight into the effects of agricultural activities on environmental degradation, climate change and health and vice versa based on the constraints encountered by the respondents.

\subsection{Effects of agricultural activities on environmental degradation and climate change}

- $\quad$ Figure 1 shows the average depth of the bore-well is $979.65 \mathrm{ft}$. among the respondents and 115 i.e. $38.33 \%$ out of 300 have the bore well whereas, 185 i.e. $61.67 \%$ of respondents are in rainfed conditions. Kasba block in the Sub-district is the driest among all other blocks and it takes the first position for the average depth of bore-well which is the deepest in the sub-district i.e. 1347.37 feet, and 19 i.e. $31.67 \%$ out of 60 respondents has it which is the least among the other blocks of the sub-district whereas, 41 i.e. $68.33 \%$ responding farmers are in rain-fed conditions. The government has stopped giving loans for installing the bore-well in this block. Farmers struggle a lot to irrigate their fields in this area. Yeldur block in the sub-district holds the second position with an average depth of the bore-well as 1013.91 feet among the respondents and 23 i.e. $38.33 \%$ of respondents out of 60 are in irrigated conditions and 37 i.e. $61.67 \%$ are in rain-fed conditions. Nelvanki block holds the third position for the average depth of the bore-well i.e. $924.13 \mathrm{ft}$. and out of 60 , only 23 i.e. $38.33 \%$ of respondents are in irrigated condition 37 i.e. $61.67 \%$ of them are in rain-fed condition. Ronur block has the fourth average depth of bore well i.e. $960 \mathrm{ft}$. and 21 i.e. $35 \%$ out of 60 respondents in this block have it and 39 i.e. $65 \%$ are those who don't have the bore-well. Rayalpad block has the least average depth of bore-well i.e. $730.17 \mathrm{ft}$. and the highest number of respondents among all the blocks, 29 farmers i.e. $48.33 \%$ farmers out of 60 have the bore-well and 31, that is $51.67 \%$ don't have the same. Therefore, there is scope for the expansion of agricultural activities in this block. Due to groundwater depletion, the bore-well has dried off for many farmers. Therefore, those farmers who were growing mulberry and other vegetables have stopped cultivating it and this has drastically affected their income.

- In table 2 we could see, $100 \%$ of the respondents say that the fertilizer they use is not based on the recommendation of the authorized person. Chemical fertilizers and pesticides are sold in the market openly and there is no provision such as the issue of chemical fertilizer based on any prescription or the calculated amount of nutrients in the soil mentioned in the Soil Health Card. $31.25 \%$ of respondents say by increasing the dose of chemical fertilizer they could increase the yield but $100 \%$ of them don't think that the use of fertilizer could adversely affect the soil. It shows that respondents have less knowledge about the side effects of chemical fertilizers on soil therefore, they need to be also educated about it.

\subsection{Effects of climate change and environmental degradation on agriculture}

- $67.18 \%$ of respondents say there is a deficit rainfall (table1) but we could see from the literature review that average rainfall in the sub-district is $745 \mathrm{~mm}$ which is not less but, uneven and untimely. Monsoon has shifted. It is confusing farmers and leaving them with a question mark about their yield and income.

- $\quad 66.88 \%$ of respondents have marked Price fluctuation and ranked it as a second genuine (Table 1). In Peninsula India, the first yield used to be from Kerala followed by Karnataka, then Andhra Pradesh, and then Tamil Nadu. According to the APMC database, all the South Indian states i.e. Kerala, Karnataka, Andhra Pradesh, Telangana and Tamil Nadu, receive the yield especially of mango at the same time (Open Government Data Platform India, 2017) due to Climate Change and Global Warming which creates a surplus. It leads to wastage and loss of profit margin for the mango growers.

- $100 \%$ of respondents say more dose of chemical fertilizer doesn't affect the soil\& its future productivity. $17.81 \%$ don't have any clue about the side-effects of pesticides. $31.25 \%$ of respondents still think more use of chemical fertilizer could increase the yield (Table 2). During the focused group discussion, we found out that the flesh in mangoes is reducing every 
year. Increasing the use of chemical fertilizer and less irrigation could be the reason behind it.53.43\% of respondents agreed that they lack knowledge about pests and diseases (Table 1). A scientist posted in Mango Development Centre, Hogalagere in Srinivaspur, and focused group members (which includes sellers of pesticides and fertilizers in the sub-district namely Lakshmipur, Addagal and Srinivaspur town) say that the disease 'Thrips' was recently introduced in the sub-district due to lack of irrigation and overuse of chemical fertilizer. Mango doesn't require much chemical fertilizer, but as the farm size has been reduced over the years, farmers practice integrated farming systems in the mango orchard. Therefore, while growing other crops in each season they apply chemical fertilizer which harms the mango yield and quality.

\subsection{Effects of agricultural activities and environmental degradation on health}

- $100 \%$ of respondents apply the chemical fertilizer and pesticides based on their assumptions as there is no need for a prescription from an authorized person to purchase it. The average use of the DAP, SSP, Urea and other fertilizer per acre are $150,200,180$, and $300 \mathrm{Kg}$ by $100 \%$, $31.25 \%, 100 \%$, and $38.75 \%$ of respondents, respectively in a mango orchard under the integrated farming system (Table 2). Whereas, the literature says there is a need for Nitrogen, Phosphorus, and Potassium (NPK) only $1 \mathrm{~kg} /$ tree. So we could see there is a huge difference in the amount of fertilizer used and the actual amount of fertilizer to be used.

- $100 \%$ of respondents don't use organic fertilizer because it is highly-priced compared to chemical fertilizer (Table 2).

- $100 \%$ of respondents are not aware of the side-effects of chemical fertilizer and pesticides on health and the environment (Table 2). We have found out in the focused group discussion that the application of the chemical fertilizer has increased drastically over the years to enhance the yield and earn more money. The Government of India provides a lot of subsidy towards plant protection and chemical fertilizers are also sold at a subsidized rate. Whereas, organic fertilizers are way too costly.

- $17.81 \%$ of respondents don't think that pesticides could adversely affect the health and the environment (Table 2). The use of Single Super Phosphate and other fertilizers like Diammonium phosphate (DAP) has increased over a while.

- $\quad 9.38 \%$ i.e. 30 respondents who use calcium carbide for artificial ripening are the wholesaler too. There are no other less harmful chemicals such as Ethylene and Ethephon are used for artificial ripening, it shows that calcium carbide is sold to the wholesaler in the open market (Table 2).

\section{CONCLUSION}

The research speaks about various constraints faced by mango growers. Unseasonal rainfall and rise in temperature are leading to late flowering is leading to late yield. It leads to flooding of mangoes that triggers the supply curve in the wholesale market, as from all the south Indian states the due to climate change mangoes orchards yield at the same time. There is no processing industry in the sub-district. Therefore, farmers are left with no options than to sell the mangoes at a low price which is less or equal to their production cost. Farmers are in a dilemma that the more they use chemical fertilizers and pesticides the more the yield will be. There is no authorized person from whom they have to take a prescription to use pesticides and chemical fertilizers. They use fertilizers and pesticides which, is recommended by shop-keepers. The organic fertilizers are highly-priced compared to chemical fertilizers. Therefore, farmers use more chemical fertilizer as they think it would give those more yields which, will in-turn enhances their profit margin. The APMC wholesale commission agents also charge a much higher commission than set by the government. They follow this practice because they have to distribute the mangoes and generate profit as there is no storage facility. The commission agents also use Calcium Carbide to artificially ripe mangoes and earn money out of it as soon as possible. Srinivaspur is dry land. The rainfall is on an average the same every year but over a while uneven and untimely. The introduction of bore- 
well in the sub-district has made cultivation of many crops possible but, the ground-water has been over-exploited over years as it is the only source of irrigation. Many farmers have witnessed drying and increasing depth of their bore-wells which has an adverse effect on the productivity of crops. Many farmers have stopped growing mulberry. The government has asked many farmers to cut Nilgiri plantation to prevent ground-water depletion. Over the years the land holdings in the subdistrict have also become small. Many farmers are now seeming to have an alternative occupation and they are making their children study different courses so that they could have a white-collar job.

\section{FUTURE DELIBERATION}

- The mango growers should be given the knowledge and techniques of modern irrigation methods with an available limited resource of water.

- There is a need for small types of machinery which would suit for horticulture farm like mango orchard.

- Farmers should be provided with training in an integrated farming system.

- Mango processing units should be developed on a small scale for checking the price level and employment generation.

- The increased role of APEDA in providing export facilities for mango pulp.

- Farmers should be encouraged to switch over to organic farming and a reduction in the usage of chemical

\footnotetext{
Funding: This study did not receive any specific financial support.

Competing Interests: The authors declared that they have no conflict of interests.

Contributors/Acknowledgement: All authors participated equally in designing and estimation of current research.

Views and opinions expressed in this study are the views and opinions of the authors, Asian Journal of Agriculture and Rural Development shall not be responsible or answerable for any loss, damage or liability, etc. caused in relation to/arising out of the use of the content.
}

\section{References}

Arphaxard, I. M., Bernard, M. G., and Paul, N. N. (2019). Analysis of banana production practices and constraints in Embu County, Kenya. Asian Journal of Agriculture and Rural Development, 9(1), 123-132.

APEDA Ministry of Commerce \& Industry (2020). Fresh Fruits \& Vegetables. New Delhi, New Delhi, India. Retrieved from https://apeda.gov.in/apedawebsite/six_head_product/FFV.htm.

Chennailyil Oru Mazhaikkaalam (2019). Mango showers likely in a few places over Karnataka \& Kerala. Chennailyil Oru Mazhaikkaalam. Chennai, Tamil Nadu, India. Retrieved May 5, 2020, from https://chennairains.com/mango-showers-karnataka-kerala/.

Department of Agriculture, Cooperation \& Farmers Welfare (2014). Soil Health Management(SHM) Under the National Mission for Sustainable Agriculture (NMSA). New Delhi, Delhi, India.

Department of Horticulture (1997- 2015). Horticulture crop statistics of Karnataka state at a Glance. Bangalore: The Directorate of Horticulture. India

Dissanayake, C., \& Chandrajith, R. (2009). Phosphate mineral fertilizers, trace metals and human health. Journal of the National Science Foundation of Sri Lanka, 37(3), 153-165.

Ganesan, R. (2014). Are EU-rejected mangoes safe for India? Mumbai, Maharashtra, India. Retrieved May 12, 2020, from https://www.business-standard.com/article/specials/are-eurejected-mangoes-safe-for-india-114050901365_1.html.

Government of Karnataka (2016). District irrigation plan- Kolar district. Kolar: Government of Karnataka, India 
Goyal, T. M., Mukherjee, A., \& Kapoor, A. (2017). India's exports of food products: food safety related issues and way forward. New Delhi: Indian Council for Research on International Economic Relations. Retrieved from https://icrier.org/pdf/Working_Paper 345.pdf.

Gupta, D., Chatterjee, S., Datta, S., Veer, V., \& Walther, C. (2014). Role of phosphate fertilizers in heavy metal uptake and detoxification of toxic metals. Chemosphere, 108, 134-144.

Kahangi, E. M. (2002). Constraints and sustainable solutions for adoption of TC banana technology and marketing. Acta Horticulturae, 638, 441-447. doi.org/10.17660/actahortic.2004.638.56.

Kamalapathi, R. (2017). Mangoes arrive early in Telangana. Hyderabad, Telangana, India. Retrieved from https://www.deccanchronicle.com/nation/in-other-news/220117/mangoesarrive-early-in-telangana.html.

Khan, N. (2017). Know about fruit ripening agents \& the harmful effects of artificial ripening of fruits. The Logical Indian. (N. K. Khan, Ed.) New Delhi, New Delhi, India. Retrieved from https://thelogicalindian.com/story-feed/awareness/artificial-ripening-of-fruits/.

Kumar, M. (2018). As prices crash, Ramanagaram farmers dump mangoes on the road. Ramanagaram, Karnataka, India. Retrieved from https://www.thehindu.com/news/national/karnataka/as-prices-crash-farmers-dump-theking-on-the-road/article24073856.ece.

Kuruvilla, A. (2020). Climate deals a blow to Muthalamada farmers. Kochi, Kerala, India. Retrieved from https://www.newindianexpress.com/states/kerala/2020/jan/08/climatedeals-a-blow-to-muthalamada-farmers-2086629.html.

Leandro, N. F. (2016). Nutrient contents in 'tommy atkins' mango leaves at flowering and fruiting stages. Engenharia Agrícola. Retrieved from https://www.scielo.br/scielo.php?pid=S0100$69162016000601073 \&$ script $=$ sci_arttext.

Shiferaw, B., Hellin, J., \& Muricho, G. (2011). Improving market access and agricultural productivity growth in Africa: what role for producer organizations and collective action institutions? Food Security, 3(4), 475-489. doi.org/10.1007/s12571-011-0153-0.

The Better Home (2018). Fresh mangoes three times a year? meet the farmer who created the unique 'Sadabahar'. The Better Home. Bengaluru, Karnataka, India. Retrieved from https://www.thebetterindia.com/140411/farmer-created-sadabahar-mangoes-kishan$\underline{\text { suman/ }}$

Wuana, R., \& Okieimen, F. (2011). Heavy metals in contaminated soils: a review of sources, chemistry, risks and best available strategies for remediation. ISRN Ecology, 1-20. doi.org/10.5402/2011/402647. 